\title{
A Gender-Based Study to Investigate Saudi Male and Female EFL Learners' Satisfaction Towards the Effectiveness of Hybrid Learning
}

\author{
Fahmeeda Gulnaz ${ }^{1}$, Amani Dakheel Allah Althomali ${ }^{1} \&$ Daliyah Hesham Alzeer ${ }^{1}$ \\ ${ }^{1}$ English Language Centre, Taif University, Taif 21974, Saudi Arabia \\ Correspondence: Fahmeeda Gulnaz, Assistant Professor, English Language Centre, Deanship of Supportive \\ Studies, Taif University, P. O. Box 888, Taif 21974. E-mail: fahmeedagulnaz@gmail.com
}

Received: June 27, $2020 \quad$ Accepted: July 28, $2020 \quad$ Online Published: July 30, 2020

doi:10.5539/ijel.v10n5p321 URL: https://doi.org/10.5539/ijel.v10n5p321

\begin{abstract}
Since the transmission of knowledge has started, it solely relied on traditional teaching methods but ever since technology-mediated instructions have emerged, they potentially brought a revolution in how we teach, when we teach, from where we teach and what gadgets, modes and apps can better cater learners' interest and motivation. In this context, hybrid learning is a novel approach in academic settings that embraces advantage of the retention of face-to-face component of traditional classes and e-learning environment. The present study aims at investigating Taif University's male and female English as Foreign Language (EFL) learners' satisfaction towards the onsite and online learning environments. An opinionnaire with 20 items was developed with closed ended questions by employing Likert's five-point scale to collect the data from 200 male and female EFL participants of Taif University, represents quantitative dimensions of the study. The research tool is designed to measure learners' satisfaction that is further categorized into five subscales. These include: (a) learners' satisfaction with the instructor and their real-time feedback; (b) perceived ease of use of technology and internet; (c) effective course content and interactive and collaborative activities; (d) finally engaging nature of hybrid learning and its impacts on learners' interest and motivation. The study finds no significant differences in male and female participants' perceptions regarding effective delivery of hybrid instructions except meek variations in male and female learners' preferences in perceived ease of use of technology. The statistics reveal that male participants and their female counterparts slightly differ in their satisfaction level towards the technical problems faced by them in recording their scores, flexibility in terms of time and space, and in smooth completion of online activities. Finally, the study provides few recommendations to fix certain issues and improve the quality of hybrid learning environment.
\end{abstract}

Keywords: effectiveness of hybrid learning, male and female EFL learners' satisfaction, gender-based, technology-mediated instructions

\section{Introduction}

It has always been one of the main objectives of the Saudi Ministry of Higher Education to provide quality of education by hiring highly qualified academic staff and utilizing multiple learning environments to supplement traditional learning environment to meet the standards of 21st Century. In the same backdrop, most of the Saudi Universities are using Computer Assisted Language Learning (CALL) as a preferred mode of instruction to meet several ends; at one-point trigger learners' mastery of the course content and at another point address varied learning styles of the learners, etc. The increasing interest of Saudi Universities in computer-mediated instructions necessitated researchers to measure Taif University's EFL learners' satisfaction towards the components of hybrid learning, such as instructor, course content, technology, internet and finally smooth working of both the worlds. By the same token, the premise of hybrid instruction enhances opportunities of interaction, as for instance, social interaction in physical classrooms cum flexibility of synchronous and asynchronous chat and discussions in online environment. Thus, it heightens learners' insight and understanding of the course content from diverse dimensions.

The use of computer assisted language learning made its appearance in the 1960s and introduced immense changes in the quality and quantity of teaching and learning process. Despite possessing enormous benefits, technology-mediated instruction could not entirely replace traditional learning environment. Traditional classrooms are still perceived as a token of high-quality learning since teacher is considered as an expert in 
teaching techniques, methods, knowledge of the subject, ways of motivating the learners and assessing the learning outcomes. Gulnaz, Thumali and Alzeer (2020) mention that physical learning environment and technology-driven instructional models ideally trigger learners' insight of the course content, meet the needs of varied learning styles and ultimately help accomplish desired learning outcomes. INACOL elaborates the term (cited in Leadership Series, 2009, p. 4) hybrid learning in these words: "combining online delivery of educational context with the best features of classroom interaction and live instruction to personalize learning, allow thoughtful reflection and differentiate instruction from student-to-student across diverse group of learners."

The integration of physical and virtual platforms of teaching are largely important for several reasons, as for instance; it convinces the learners that their academic knowledge is part and parcel of their social life. Moreover, technology driven education equipped the learners with the current needs of the time because traditional teaching doesn't prepare the learners to meet the challenges of 21st century (Qindah, 2018). The virtual cum face-to-face learning environments enhance learners' motivation and enthusiasm for learning as they get the opportunity to feel and work beyond the walls of school. The combination of both the teaching approaches broadens learners' horizon and enables them to receive knowledge and information from diverse channels. In this backdrop, Neumeier (2005) expresses that EFL researchers have shown satisfaction towards both the modes of instructions. In the same manner, Sharma (2010), discusses that best instructional blend exposes the learners to the optimum learning experiences. Ono, Ishihara and Yamashiro (2015) contend that in spite of giving excellent results, CALL has some disadvantages in on-site educational settings. Some of its challenges that make it hard to implement in every educational setting is its high cost and difficulty of adaptability according to the demand of modern educational scenarios. Several inquiries have been undertaken for the last two decades at different universities of Saudi Arabia to inquire the challenges, strengths, weaknesses and effectiveness of hybrid learning. A brief sketch of those studies in the context of hybrid learning in Saudi Arabia has been provided below to justify the gap between the present study and their context(s):

1) As yet, Alebaikan and Troudi (2010) conduct their research to investigate the nature of impediments and challenges encountered at Saudi universities while implementing a blended learning approach. Three major challenges have been addressed in the research, such as implementation of hybrid learning at Saudi Universities, selecting the right blend and the time issue. The study extended practical recommendations to overcome the obstacles.

2) Similarly, Alzahrani (2017) investigates in his research the importance of the provision of information and communication technology (ICT) tools to the professors and the learners for more effective learning outcomes. Moreover, he highlights the current status of the development of ICT in his study to help the decision makers and instructors to utilize them successfully by accurately assessing their learners' needs and quality of the tools.

3) In a similar vein, Al Alhareth (2013) undertakes the study to investigate the barriers that impede access of women to higher education in Saudi Arabia. The researcher believes that the opportunities for the women has certainly increased with the provision of higher education but still equality has not been observed in the division of the educational resources between both the genders. The lack of resources does not meet the educational needs of women across the country.

4) By the same token, Badawi (2009) carries out his study at the University of Tabuk to inquire the effectiveness of blended learning model in developing prospective pedagogues' teaching skills and professional expertise. The findings of the study indicate that blended learning model is more effective than face-to-face classrooms in developing knowledge of the prospective teachers whereas both the modes of instructions have the same impacts on developing their pedagogical performance.

5) Furthermore, Alseweed (2013) (cited in Alnahdi, 2019) undertakes his research at Qassim University to investigate perceptions and experiences of 37 EFL learners about the traditional and virtual modes of instructions. Moreover, another study was carried out at King Khalid University by Al Zumor et al. (2013) who investigate learners' experiences regarding promises and perils of hybrid learning in the EFL classroom.

6) In addition to this, Yushau (2006) in his work measures the impacts of online and onsite modes of instructions on learners' computer and mathematic attitude. The findings of the study indicate that both the modes of instruction triggered learners' motivation and enthusiasm towards computer and mathematics.

7) Yet another study conducted by Al-Otaibi (2010) (as cited in Al-Saleh, 2018), inquires secondary school teachers' awareness and attitudes towards hybrid learning in Tatweer schools in Makkah district. The findings show that teachers possess positive attitude towards hybrid learning. In this context, study of Ageel (2011) explores the use of the level of ICT among teachers in one of the most prominent universities of Saudi Arabia. 
He surveyed through the structured interview and found that majority of the teachers do not make use of ICT in their classrooms. In addition to this, he identified number of attitudes ranging from the idea that ICT may impede teaching learning process to their unwillingness to change traditional teaching method working since centuries. However, some of the teachers have shown their inclination towards the use of ICT. Hence, suggested for the training programs that focus on the use of ICT at educational settings.

The previous studies have been carried out at numerous universities of Saudi Arabia in different scenarios, such as; the level of its use, challenges, promises and perils of virtual platform cum physical classrooms but so far no research has been undertaken to measure the level of satisfaction of Taif University's male and female EFL learners about the effectiveness of hybrid learning environment. The aim of this study is to investigate the effectiveness of different components of hybrid learning comprising, learners' satisfaction with the instructor, course content, internet, perceived ease of use of technology and both the modes of instructions.

\section{Literature Review}

The history of educational enterprise has seen many changes in its infrastructure to inaugurate innovative ways of delivering the instructions. As an end-product of these measures, hybrid learning has emerged as an innovative paradigm in modern education. Launer (2010) perceives that language learning process is a life-long process, which is highly complex. In order to provide better learning opportunities, address challenges of expansion and catering needs of the diverse learning styles of the learners, academicians introduced face-to-face cum technology mediated instructions in teaching and learning scenarios. However, in this process they came across numerous challenges, as for instance; financial obstacles, lack of enough resources and teaching expertise to effectively deliver online instructions. The combination of face-to-face cum virtual instructions reflects saying of Swami Vivekanand, who expresses that: "if people cannot reach school, schools should reach them" (Lalima \& Dangwal, 2017, p. 130). The idea of accessing learners' home is unique but its practical implementation involves detailed planning and complex processes. In the context of its successful implementation, one of the important variables is learners' satisfaction and its measurement is considered as an important predictor for smooth delivery of hybrid learning.

Hybrid learning approach has been widely used at educational settings because its properties inherently possess the dynamics of flexibility of anytime and anywhere for the successful delivery of course content and social interaction. The hybrid learning environment has been incorporated at Taif University in 2017 for bachelor degree courses. The study has been undertaken to investigate differences in the satisfaction level of male and female EFL learners of Taif University to inculcate improvements and ensure smooth running of the program. For the purposes of present study, the data was collected from 200 male and female EFL learners of Taif University to know their perceptions, who were studying Cambridge UNLCOK and English Unlimited Special Edition (EUSE) to pursue their bachelor degrees. The next section has been given over to the different aspects of literature review, which are associated with the learners' satisfaction and successful execution of the hybrid learning approach.

\subsection{What Is Hybrid Learning?}

In recent years, language learning has moved beyond its traditional style of teaching, i.e., a combination of face-to-face and online mode of instruction called hybrid learning environment. Many scholars defined it in these words that it: "is not a simple combination of classroom instruction with e-learning, but comprises a standard instructional setting (class meetings) as well as offline activities outside the classroom (tutorials, classes from other institutions on the campus, peer-review workshops), and computer-mediated learning (online lessons)" (Bärenfänger, 2005; Pöysä, Lowyck, \& Häkkinen, 2005; Paechter, 2004; Arnold, 2004; Waddoups \& Howell, 2002). Bärenfänger (2005) discusses that the scholars who blend classroom instruction and virtual learning, the "half bricks, half clicks concept", ignore the point that hybrid learning includes several other ways of acquiring knowledge and information. He mentions that hybrid learning model of Brigham Young University includes all the channels of instructions, apart from technology-mediated environment that learners utilize outside the classroom, as for instance; tutorials, discussion groups, or information retrieval in a library. Oliver and Trigwell (2005) note that combination of only face-to-face classroom with the virtual learning or distance education is a narrow description of hybrid learning.

However, some other researchers take the concept of blended learning and hybrid as akin to each other (Mason \& Rennie, 2006; Thompson, 2003; Alshwiah, 2010). The present study is based on the stance taken by the scholars, who considered both the channels of instructions similar to each other. In this context, Waddoups and Howell (2002, p. 2) define hybrid learning: "hybridization occurs when on-campus educators adopt distance education technologies and practices, and when distance education organizations adopt/adapt campus-based 
educational practices". In addition to this, Buzzette-More (2008) states that hybrid learning model efficiently and effectively disseminates knowledge, supports delivery of instruction, enhances information (Young, 2002) and sparks learners' satisfaction (Buzzetto-More \& Sweat-Guy, 2006; Campos \& Harasim, 1999; Dziuban \& Moskal, 2001; Rivera, McAlister, \& Rice, 2002; Wu \& Hiltz, 2004). Few studies assume that in future hybrid learning would be the most popular mode of instruction in higher education (Allen \& Seaman, 2003; Buzzetto-More \& Sweat-Guy, 2006; Lorenzetti, 2005; Young, 2002). The option of the convergence of both is adopted by Taif University where traditional classrooms and virtual platforms are working parallel to each other to deepen learners' insight and understanding of the course content.

\subsection{What's Learners' Satisfaction?}

An important course learning outcome that cannot be measured through attendance or formative or summative assessment is learners' satisfaction. Learners' satisfaction is perceived an important indicator in measuring the quality of any educational program and in the context of present study 'hybrid learning approach'. The Sloan Consortium explains learners' satisfaction as, "Students are successful in the learning and are pleased with their experience" (Moore 2009, p. 92). Sweeney and Ingram (2001, p. 61) define the concept as: "the perception of enjoyment and accomplishment in the learning environment." The above-mentioned definitions reflect that learners' satisfaction is based on their achievement, pleasure and enjoyment with the learning experience. Thurmond, Wambach, Connors and Frey (2002) describe student satisfaction as: "a concept that reflects outcomes and reciprocity that occur between students and an instructor." Zhao and Yuan (2010) declare that instructor's instant feedback sparks learners' motivation and enhances their satisfaction. Bowyer and Chambers (2017) discuss that for a researcher or teacher, success of a course may be based on the course learning outcomes whereas learners' satisfaction accounts for their personal experiences from the course. Collins Cobuild English Dictionary (1999) (Cited in Giannousi, Vernadakis, Derri, Michalopoulos, \& Kioumourtzoglou, 2009, p. 62) define satisfaction that it is: "the pleasure or contentment that one person feels when she/he does something or gets something that she/he wanted or needed to do or get". Chang and Fisher (2003) believe the same and attach learners' satisfaction with the successful accomplishment of the course. Contrary to this, Moore and Kearsley (2005) observe that learners' satisfaction cannot be attached with their academic achievement. Likewise, Bollinger and Martindale (2004) add that satisfaction instills curiosity, which ultimately enables the learners to achieve success.

DeBourgh (2003) believes that learners' satisfaction is partly connected with their subsequent enrollment in online courses. The same idea is reinforced by Arbaugh (2000), who notes that learners' subsequent enrollment in the same course is a strong indicator of their satisfaction with the quality of the course. Both the opinions indicate that learners have shown their satisfaction with overall scheme of the online course from planning to delivery of the course content. In the same context, Long (1989) mentions that satisfaction means learners positive behavior and excitement towards the course. Wu, Tennyson and Hsia (2010) add to this by claiming that learners' satisfaction is integrated with their attitude and beliefs that emanate from the benefits which they ultimately receive from the course. The findings of the study of Dziuban et al. (2005) are consistent with the present study who reports instructor's satisfaction with the hybrid course and mention that students' learning and performance is similar or somehow better in technology-mediated instruction than traditional face-to-face learning environment.

\subsection{Learners' Satisfaction with the Instructor}

Instructor is a strong indicator in learners' satisfaction with the course content (Finaly-Neumann, 1994; Williams $\&$ Ceci, 1997). The instructor plays a pivotal role in the teaching and learning process, no matter which modes of instruction they are teaching in. Their attitude towards e-learning has a crucial effect on learners' satisfaction. As for instance; a less motivated instructor would not expect their learners to be with high satisfaction and motivation. This attitude may lead to reduce the effectiveness of e-learning program. The most important variable in the study of Marks, Sibley and Arbaugh (2005), is the measurement of learners' satisfaction towards the instructor and the previous supporting studies on the importance of instructor's role (Easton, 2003; Martins \& Kellermanns, 2004).

DeBourgh (1999) (Cited in Abou Naaj et al., 2012) claims that instructor's performance; synchronous and asynchronous interaction and real-time feedback have strong correlation with learners' satisfaction (Hiltz, 1993). In addition to this, few researchers associate learners' satisfaction with the instructor's counseling time for the learners and flexibility in time and plan (Moore \& Kearsley, 1996). Synchronous interaction and instant feedback of the teacher not only enhances learners' curiosity for learning but also guarantees high grades and their satisfaction. Finaly-Neumann (1994) believes that in hybrid learning instructor assumes the role of not only a 
facilitator but also motivator. The real-time feedback on learners' participation and assignments keeps their excitement and satisfaction persistent and high (Smith \& Dillon, 1999). In hybrid learning, planned synchronous interaction on regular basis maintains learners' interest and motivation (Mood, 1995) and prevents them from frustration (Hara \& Kling, 2001; Wegerif, 1998). Mood (1995) highlights that at the beginning of the semester learners should be informed about course learning outcomes and objectives. Learners' level of anxiety can be reduced if they know what they are expected to perform and what learning goals they have to achieve. Instructors should praise learners' participation and provide them updated knowledge and monitor their performance. Learners should always be at the heart of classroom activities so that they can structure their own learning experiences.

\subsection{Learners' Satisfaction with the Perceived Ease of Use of Technology}

The research in the field of information technology indicates that learners' usability and their satisfaction are the crucial components in assessing success of e-learning systems (Delone \& Mclean, 2003; Lewis, 2002; Virvou \& Katsionis, 2008). Davis (1993) defines perceived ease of use technology as the extent individuals feel satisfied each time by completing online activities. Liaw and Huang (2013, p. 17) report that perceived satisfaction can be defined as: "user acceptance of information systems and the degree of comfort involved in using them". It can also be taken as: "the pleasure or contentment one feels when s/he performs a required or desired action and experiences the result" (Shee \& Wang, 2008, p. 895). Satisfaction is the composite of individual's feelings or view point towards the several factors that influence a certain situation. In the context of technology, Doll and Torkzadeh (1988) explain satisfaction as the feeling of positive attitude towards a given system.

In the context of human-computer interaction, user satisfaction is perceived as the feeling of comfort and contentment received from interaction. The user satisfaction can be perceived as the "subjective sum of interactive experiences" affected by many factors in the process of interaction (Lindgaard \& Dudek, 2003). In the past many attempts have been made to evaluate user satisfaction and found that it is a complex construct, which varies from person to person according to their experiences. As for instance; in e-learning environment, the user satisfaction is certainly affected by the quality of the system, content and its usability (Kim \& Ong, 2005). The research of Liu, Liao and Pratt (2009) suggests that the use of rich media with diverse interactive functions create enormous impacts on learners' satisfaction. The assessment of educational software can be done by measuring its impacts on learners' satisfaction. However, the study of Virvou and Katsionis (2008) report that usability of technology is considered as a significant factor influencing educational effectiveness. The international standard ISO 9241 (Cited in Liaw \& Huang 2013, p. 17) provides guidance on its usability and explains it as: "the extent to which a product can be used by specified users to achieve specified goals with effectiveness, efficiency and satisfaction in a specified context of use". Hence, higher the degree of satisfaction towards an IT system signifies not only higher the level of willingness to use it but also higher the quality of the particular system.

\subsection{Learners' Satisfaction with the Technology and Internet}

In present study significant differences are noticed in the perceptions of male and female participants regarding the use of technology and up-gradation of score and progress of the learners. Unlike this, Sun, Tsai, Finger, Chen and Yeh (2008), didn't report any variations in the opinions of the learners. They believe that in e-learning environment poor networking and technology reduces learners' satisfaction and discourages them from taking online courses. Many scholars emphasize that the quality of internet and technology influence satisfaction of the learners in e-learning setting (Piccoli et al., 2001; Webster \& Hackley, 1997). The higher the quality of technology ensures higher the satisfaction of the learners (Hiltz, 1993; Piccoli et al., 2001; Webster \& Hackley, 1997). For discussion and learning purposes video conferencing can also be used in e-learning (Isaacs, Morris, Rodriguez, \& Tang, 1995). Therefore, quality of internet and technology are perceived as the important factors in e-learning. The empirical research carried out by Webster and Hackley (1997) on 247 participants studying technology-mediated distance learning reveals that quality of networking and technology are equally important to affect learners' satisfaction. The quality of technology is defined as the learners' perceived quality of gadgets, such as; headphone, microphone and blackboard etc. Similarly, the quality of internet is perceived as the excellent networking that facilitates interaction and learning (Sun et al., 2008). In the context of quality of technology Belanger and Jordan (2000) declare that learners must have an access to the reliable equipment. Learners with limited access are considerably at a less advantageous position than the ones who have unlimited access. Researchers considered that the factor which influences maximum to the learners' satisfaction in e-learning environment is their access (Wegerif, 1998; Bower \& Kamata, 2000). In addition to this, Belanger and Jordan (2000) express that in order to be successful; learners must be familiar with the technology and its usage. 


\subsection{Learners' Satisfaction with the Course Content}

The quality and flexibility are considered significant aspects of the e-learning course. Flexibility in terms of elimination of the physical barriers in an e-Learning course is a strong indication of student satisfaction. It ignites robust interaction among the learners that ultimately furnishes opportunities for cooperative and collaborative learning (Brandon \& Hollingshead, 1999; Salmon, 2000). Beyond the limitations of time and space, learners can initiate communication from anytime and anyplace (Harasim, 1990; Leidner \& Jarvenpaa, 1995; Taylor, 1996). Many researchers investigated different components of hybrid learning. As for instance; Sun, Tsai, Finger, Chen and Yeh (2008) probe into the following elements of learner satisfaction in their study, i.e., instructor, technology, course design and environment dimensions. The study of Shee and Wang (2008) investigates similar factors such as interaction between learners and teachers, perceived ease of use of technology, and course flexibility. Sitter et al. (2009, p. 45) mention that in online learning students and instructor face similar kinds of challenges. The instructors have to design the course material that includes content and quality to meet the learning objectives effectively without falling into the "course-and-a-half syndrome" (Skibba, 2006). Similarly, learners should have the ability to understand the course content to achieve the learning goals (Skibba, 2006; Stodel et al., 2006). Teachers and the main stakeholders of the learning process report that the course content and design facilitated learning though it was highly challenging.

The study of Sitter et al. (2009) finds no significant differences in the perceptions of the learners and faculty members which indicate that blend of both environments provided them robust teaching and learning experiences. In addition to this, they add that the key to achieve learners' satisfaction and maximum learning outcomes is the instructor's ability to create the course content that addresses learners' needs and interests (Dziuban et al., 2005), maintain their interest and motivation and at the same time give them challenging time (Stodel et al., 2006). In the study of Sitter et al. (2009), significant differences were found in the opinions of the participants about the use of technology. Learners found it easy to use the technology employed by the program, whereas the faculty members experienced the use of technology somehow difficult in completing the assignments. The variation in the perceptions may be due to the unfriendly nature of the online learning platform used in this program. The factor of quality is another important aspect that influences learners' satisfaction in e-learning (Piccoli et al., 2001). The interactive communication and media presentations provided by constructive learning model help learners develop their thinking skills and conceptual knowledge (Leidner \& Jarvenpaa, 1995). The reviewing of previous studies and their context(s) and investigating differences in the level of male and female EFL learners' satisfaction towards the e-learning and conventional classrooms have been perceived as an important factor to understand the effectiveness of hybrid learning approach.

\section{Method}

\subsection{Research Questions}

The following questions have been formulated for the present study:

1) Why does understanding of the participants' satisfaction towards the effectiveness of hybrid learning approach indispensable?

2) Why does correlation of learners' satisfaction with the instructor, technology, internet, course content and virtual platform cum conventional classrooms significant?

3) Why do we need to measure the differences in the satisfaction level of Saudi male and female EFL learners towards the effectiveness of hybrid learning environment?

\subsection{Research Hypothesis}

The present study has following null hypothesis:

1) There does not exist any gender-based statistically significant differences in the satisfaction level of male and female EFL participants about the effectiveness of hybrid learning.

2) There does not exist any correlation between the learners' satisfaction and variable of instructor, technology, internet, course content and perceived ease of use of hybrid learning.

\subsection{Research Design}

The present empirical study is designed to measure satisfaction level of Taif University's EFL learners about the effectiveness of essential variables of hybrid learning. The survey was comparative in nature in which responses of the participants were quantitatively analyzed to determine statistically significant differences in the satisfaction level of male and female EFL learners about the effectiveness of hybrid learning. 


\subsection{Participants}

The present study randomly selected 200 male and female EFL learners to collect the data. Arabic version of the opinionnaire was administered to the randomly selected EFL learners of Taif University. The researchers received eighty-five $(n=85)$ valid responses from female EFL learners and eighty-two $(n=82)$ from the male learners. A total of $167 \mathrm{EFL}$ learners participated in the survey.

\subsection{Instrumentation}

The researchers thoroughly probed into the several relevant studies which have been published during the last two decades to develop instrument for the present study (See for example Sun, Tsai, Finger, Chen, \& Yeh, 2008; Liaw \& Huang, 2013; Buzzette-More, 2008; Haytko, 2001; Abou Naaj et al., 2012; Giannousi et al., 2009; Edalati, 2013). A 20 -item Likert-scale instrument designed to measure learners' satisfaction that further divided into five variables, i.e., i) learners' satisfaction with the CLMS; ii) interaction with the instructor; iii) course content; iv) engaging nature of hybrid learning; and v) perceived ease of use of technology and internet. The present study set-forth three $(\mathrm{n}=3)$ research questions in relation to the 20 -items displayed in the five-tables in the section of "results and discussion".

\subsection{Reliability and Validity}

An initial version of the opinionnaire was developed by the researchers after reviewing the previous context(s), to measure participants' level of satisfaction about the five-variables narrowed down in the research tool. That initial draft was sent to the three experts and their suggestions were added to achieve face and content validity of the survey. Then twenty-one English language teachers of the same field pilot-tested the opinionnaire. The Cronbach's Alpha reliability test was run on the data generated through the pilot-test to determine reliability of the research tool. The results reflect reasonable level of reliability of .871 .

Table 1 . Reliability coefficient

\begin{tabular}{ll}
\hline Number of Cases & 21 \\
Number of Items & 20 \\
Alpha & .871 \\
\hline
\end{tabular}

The final version of the research tool was administered to the participants to generate the data.

\subsection{Data Collection}

After determining validity and reliability of the research instrument through a standardized procedure, the researchers administered final version of 20-item strongly-agree to strongly-disagree Likert-scale opinionnaire to the randomly selected 200 male and female EFL learners of Taif University. Similarly, the researchers have provided Arabic version of the tool to the target population of this empirical study. Henceforth, the researchers received 167 valid responses out of 200 randomly selected participants of this study.

\subsection{Data Analysis}

The data generated from the research tool was coded, manually entered and comparative statistics in terms of means, range and standard deviations of the responses of the 167 male and female EFL learners were calculated using version 23 of Statistical Package for Social Sciences (SPSS). Independent-Samples T-test was run to identify differences in the perceptions of male and female cohort studying at Taif University. The higher the mean value means the highest importance assigned by the participants. The data was tabulated to discuss mean variations of each item with support and evidence of previous studies in the section of 'results and discussion'.

\section{Results and Discussion}

This section elaborates the discussion related to the data gathered from the participants' feedback and support results of the present study with the findings of the previous works. 
Table 2. EFL learners' satisfaction with the efficient working of CLMS

\begin{tabular}{|c|c|c|c|c|c|c|c|}
\hline No & Statements & Gr. & $\mathrm{N}$ & M & .df & P value & \\
\hline \multirow[t]{2}{*}{1.} & I easily created my account on Cambridge Learning & F & 85 & 3.8518 & 165 & $\mathrm{p}>.254$ & No \\
\hline & Management System (CLMS). & M & 82 & 3.8185 & 164.835 & .254 & \\
\hline \multirow[t]{2}{*}{2.} & I found it easy to login to my online account on CLMS. & $\mathrm{F}$ & 85 & 3.4282 & 165 & $\mathrm{p}>.013$ & No \\
\hline & & M & 82 & 3.9844 & 163.795 & .013 & \\
\hline \multirow[t]{2}{*}{3.} & I found instant technical help and support on Cambridge & $\mathrm{F}$ & 85 & 3.5824 & 165 & $\mathrm{p}>.579$ & No \\
\hline & Learning Management System (CLMS). & M & 82 & 3.5283 & 161.124 & .577 & \\
\hline \multirow[t]{2}{*}{4.} & CLMS allows me to work in my own comfort zone in terms of & $\mathrm{F}$ & 85 & 3.4282 & 165 & $\mathrm{p}<.042$ & Yes \\
\hline & time and space. & $\mathrm{M}$ & 85 & 4.8922 & 162.872 & .042 & \\
\hline
\end{tabular}

Table 2 contains statistical data related to the male and female EFL participants' satisfaction towards the functionality of Cambridge Learning Management System (CLMS). The comparative statistics indicate highly preferred items with huge differences in the opinions of the participants. High mean has been reported for item 4, which mentions that CLMS allows learners to work in their own comfort zone in terms of time and space with mean value of (mean $=4.89)$ and (mean $=3.42)$ by male and female cohort. The findings of the study are in-line with the results of the research of Bukhari and Basaffar (2019), who express that $79 \%$ of their learners strongly acknowledge that hybrid learning provides flexibility in time and space. The learners find hybrid learning an easy and autonomous mode of learning, where they can work on their own pace. Similar kinds of results are received by Bonk and Graham (2012), who report it a comfortable tool that facilitates autonomous learning with flexible time and space. The terms 'comfort zone and flexibility' have been explained by Anderson (2008), who expresses that learning which transcends beyond the limits of time, space and individual. He mentions that learning for: "anyone, anytime, anywhere" (Broadbent, 2000; Casella et al., 2007; Hasan, 2006). It includes many paradigms, as for instance; self-pace of the learner, medium of content delivery and time and place of the exam. In this backdrop, Gómez and Igado (2008) mention that hybrid learning transcends beyond the limitation of time, space and culture and provides dynamic opportunities of learning to the students. For this reason, academic institutions prefer to adopt hybrid learning over online or onsite mode of instruction.

The female counterpart has assigned mean value of (mean $=3.42$ ) to item 2 , whereas male counterpart of this cluster has reported mean value of (mean $=3.98$ ) for this category. The item states that: 'I found it easy to login to my online account'. Few studies indicate that perceived ease of the use of learning management system may enhance learners' satisfaction (Chang \& Tung, 2008; Shee \& Wang, 2008). In this pretext, Levy (2007) expresses that effective course design and efficient delivery of the onsite and online delivery of instructions may lead to learners' satisfaction to continue the course or vice versa may cause drop out of the learners (Chiu, Hsu, Sun, Lin, $\&$ Sun, 2005). Item 1 receives almost equal preference of the participants with a mean value of $(m e a n=3.81)$ and $($ mean $=3.85)$ from male and female cohort, which mentions that learners found it easy to create their account on CLMS. The least ranking item of this cluster, which indicate that learners received instant technical support from the technical staff whenever they need it, partially coincides with the results of Woods, Baker and Hopper (2004), who has reported that majority of the learners have shown their satisfaction with hybrid learning because its online features provided them access to the material and resources 24/7. In this context, Lin (2008-2009) discusses that lack of technology skills and Wi-Fi issues negatively influence learners' satisfaction towards online delivery of instruction. The least preferred item of this category with strikingly low differences in the responses of male and female cohort mentions that learners get instant technical help regarding any difficulty in the execution of online activities. The mean value with no striking differences, such as, (mean $=3.58)$ and (mean $=3.52$ ) by female and male participants has been allocated to the item 3. The item states that learners receive instant help and support on CLMS whenever they encounter any technical problem. Both the genders almost have similar reaction regarding technical help and support provided on CLMS. Contrary to the findings of the present study are the results of Bollinger and Martindale (2001), who report that less than $25 \%$ of the learners have shown dissatisfaction with the variables; such as, teaching methods, instructor feedback, instruments used for communication, presence of the course instructor, structure of organization's web-site and learners' personal familiarity with the use of technology. Nevertheless, $58 \%$ of the learners have shown their dissatisfaction towards the interaction in e-learning environment and similarly, $48 \%$ learners denied their participation. Moreover, $31 \%$ didn't show their satisfaction towards the effectiveness of communication in e-learning courses. In the context of present study, the strength of male and female EFL learners' responses indicates their maximum satisfaction towards the effectiveness of CLMS and conventional classrooms. 
Table 3. EFL learners' satisfaction with the perceived ease of use of technology and Internet

\begin{tabular}{|c|c|c|c|c|c|c|c|}
\hline No & Statements & Gr. & $\mathrm{N}$ & $\mathrm{M}$ & df & P value & \\
\hline \multirow[t]{2}{*}{5.} & I believe that slow internet connection impedes my & $\mathrm{F}$ & 85 & 2.3412 & 165 & $\mathrm{p}>.350$ & No \\
\hline & performance in online working. & $\mathrm{M}$ & 82 & 2.5488 & 164.868 & .350 & \\
\hline \multirow[t]{2}{*}{6.} & I complete online exercises and activities smoothly and & $\mathrm{F}$ & 85 & 4.9588 & 165 & $\mathrm{p}<.001$ & Yes \\
\hline & comfortably. & $\mathrm{M}$ & 82 & 3.9171 & 163.444 & .001 & \\
\hline \multirow[t]{2}{*}{7.} & I encounter technical problems when CLMS doesn't upgrade & $\mathrm{F}$ & 85 & 3.8612 & 165 & $\mathrm{p}<.000$ & Yes \\
\hline & my grades and progress. & M & 82 & 4.8307 & 160.049 & .000 & \\
\hline \multirow[t]{2}{*}{8.} & I assume that hybrid learning tend to make me bored and & $\mathrm{F}$ & 85 & 2.9882 & 165 & $\mathrm{p}>.406$ & No \\
\hline & socially isolated. & $\mathrm{M}$ & 82 & 3.1585 & 164.988 & .406 & \\
\hline
\end{tabular}

Table 3 contains descriptive analysis of the statements about learners' satisfaction towards their perceived ease of use of technology and internet. The participants have favored item 6, which mentions that, 'I complete online exercises and activities smoothly and comfortably,' the most with extremely high mean values of (mean $=4.95)$ by the male participant and (mean $=3.91)$ by their female counterparts. Contrary to this are the findings of Summers, Waigandt and Whittaker (2005), who report that there are several factors which indicate that learners feel more satisfied with traditional face-to-face classrooms than online mode of instruction. In this context, Lee and Lee (2008) notes that technology-mediated instructions enhance learners' performance in the course. In this category, item 7 states that learners encountered technical problems when CLMS didn't upgrade their score after completing exercises on CLMS has received positive reaction of the participants as indicated by high mean value of (mean $=4.83$ ) by the male participants and (mean $=3.86$ ) by the female counterparts with a huge variation in their experiences. In this context, the study of Chong (1998) mentions that learners who experience difficulties in the use of technology indicate lower satisfaction level (Hara \& Kling, 2003). The work of Abou Naaj et al. (2012) partially coincides with the findings of present study, who indicate no significant differences in the opinions of the participants. The maximum mean value of $($ mean $=3.7)$ has been assigned by the participants to the technology used for video-conferencing. The learners have shown their overall satisfaction to the use of technology with mean value of (mean $=3.6)$.

The average mean has been reported for the belief that hybrid learning may make the learners socially isolated and bored. The male and female participants have not reacted positively to the item 8 as indicated by the lowest mean of only (mean $=2.98)$ by the female learners and (mean $=3.15)$ by their male counterparts, respectively. In this regard, hypothesis of the study of Ali and Smith (2015) show that withdrawal rate of the learners in online courses is more than the conventional classrooms. They used attrition rate of the learners in online courses to measure their social isolation and boredom in these classes. They conclude that in the classes of computer literacy social isolation of the learners is higher than the conventional classrooms which enhance their withdrawal from the course. Similar kinds of findings are reported by the Schaeffer and Konetes (2010); who highlight same factor for the higher rate of the drop-out of the learners from online courses. The learners reportedly have shown dissatisfaction towards the program because of boredom and loneliness. Furthermore, Allen and Seaman (2013) note that there is a persistent agreement among the academicians about the lower retention rate of learners in online courses and they further add that this is a major impediment in the growth of e-learning education. In this regard, the study of Frankola (2001) reports that in online courses withdrawal rate is $20 \%-50 \%$ which is many times higher than the drop-out rate of conventional classes which is $10 \%-20 \%$.

An interesting finding of the study is that the participants of this survey have assigned extremely low mean value of (mean $=2.34$ ) by the female and (mean $=2.54$ ) by the male participants to the item 5 , which mentions that slow internet connection is an obstacle for the Saudi participants to complete online activities on CLMS. Moreover, the statistical data shows no significant differences in the responses of the participants regarding this item. The findings of the empirical research conducted by Webster and Hackley (1997) on 247 students to investigate their perceived satisfaction about technology-mediated instructions indicate that quality of technology and high-speed internet are crucially significant for effective learning experience. In the study of Bollinger and Martindale (2001), some students suggested that before enrolling the learners for the online courses the university should ensure that they know the basics of technology and how to use it. The results of their study indicate that more than $80 \%$ of the learners' have shown their satisfaction towards the instructor, reliability of technology, internet connection, access to the resources and organizational affairs. 
Table 4. EFL learners' satisfaction with the engaging nature of Hybrid learning and its impacts on their motivation and confidence

\begin{tabular}{|c|c|c|c|c|c|c|c|}
\hline No & Statements & Gr. & $\mathrm{N}$ & $\mathrm{M}$ & .df & P value & \\
\hline \multirow[t]{2}{*}{9.} & \multirow{2}{*}{$\begin{array}{l}\text { Hybrid learning effectively cater(s) learners' interest and } \\
\text { motivation. }\end{array}$} & $\mathrm{F}$ & 85 & 3.4612 & 165 & $p>.933$ & No \\
\hline & & $\mathrm{M}$ & 82 & 3.4844 & 164.602 & .933 & \\
\hline \multirow[t]{2}{*}{10.} & \multirow{2}{*}{$\begin{array}{l}\text { Physical classrooms and virtual instructions have improved } \\
\text { my English language skills. }\end{array}$} & $\mathrm{F}$ & 85 & 3.5224 & 165 & $\mathrm{p}>.250$ & No \\
\hline & & $\mathrm{M}$ & 82 & 3.7639 & 164.251 & .251 & \\
\hline \multirow[t]{2}{*}{11.} & \multirow{2}{*}{$\begin{array}{l}\text { Online and onsite modes of instruction have enhanced } \\
\text { interaction and collaboration with my fellow peers. }\end{array}$} & $\mathrm{F}$ & 85 & 3.5241 & 165 & $\mathrm{p}>.094$ & No \\
\hline & & $\mathrm{M}$ & 82 & 3.5815 & 164.997 & .094 & \\
\hline \multirow[t]{2}{*}{12.} & \multirow{2}{*}{$\begin{array}{l}\text { Face-to-face and online learning environments have } \\
\text { increased my confidence and knowledge. }\end{array}$} & $\mathrm{F}$ & 85 & 3.6371 & 165 & $\mathrm{p}>.852$ & No \\
\hline & & M & 82 & 3.5198 & 163.370 & .851 & \\
\hline \multirow{2}{*}{13.} & \multirow{2}{*}{$\begin{array}{l}\text { Hybrid learning dispenses an opportunity to the learners for } \\
\text { cheating and plagiarism. }\end{array}$} & $\mathrm{F}$ & 85 & 3.3647 & 165 & $p>.126$ & No \\
\hline & & M & 82 & 3.0244 & 164.893 & .126 & \\
\hline
\end{tabular}

Table 4 details comparative statistics of the responses of male and female EFL participants regarding their satisfaction towards engaging nature of hybrid learning and its impacts on learners' interest and motivation. This table includes 5 items in total. A high mean value of (mean $=3.76$ ) was recorded by the male cohort to the item 10 which mentions that hybrid learning makes their English language skills better. The female participants have allocated (mean $=3.52$ ) to this item. The results of Matheos and Curry's (2004) study coincide with the present study that online learning entails flexible mode, furnish multiple options of learning, diverse resources and opportunities. The male and female participants of the survey have reacted positively to the item 12 , which states that hybrid learning triggered their knowledge and confidence. The mean value assigned to this item by both the genders is (mean $=3.63)$ and (mean $=3.51)$. The highest-ranking item of this category coincides with the results of Giannousi et al. (2009), who have reported that learners' perceived ease of use of e-learning is higher than the average which manifests their overall high satisfaction with the delivery of the course content and learning experience. Biner et al. (1994) highlight that satisfied students learn the course content more easily, less likely to drop out of class, more willing to take additional online courses and convince others for the course. In a similar vein, both the genders have allocated average range of mean value to the item 11, i.e., (mean $=3.52$ ) and (mean $=3.58$ ), which states that hybrid learning provides opportunity to the learners to collaborate and interact with their fellow peers. Research indicates that learners' performance is based on the level of interactivity and collaboration among the learners (Jiang et al., 2000; Bruckman, 2002). Mason et al. (2000) add to this that the practice of hands-on activities also has significant impacts on learners' performance (Cited in Anderson, 2008).

The lowest mean value with no striking differences in learners' responses, i.e., $($ mean $=3.46)$ and $($ mean $=3.48)$ was attached by the male and female cohort to the item 9 , which refers to the learners' belief that hybrid learning activities effectively cater(s) their interest and motivation. In this context, Viadero (1999) reports that motivational techniques furnish unique learning experiences to the learners which result in their satisfaction. In the study of Bukhari and Basaffar (2019), 72\% of the learners acknowledged that onsite and online channels of instruction provide effective learning experience. Similarly, the study of Sagarra and Zapata (2008) confirms positive perception of the learners towards both the channel of instructions. In the study of Bukhari and Basaffar (2019), $67 \%$ of the learners find blended learning more interesting than face-to-face mode of instructions (Dori \& Belcher, 2005; O’Donnell, Hmelo-Silver, \& Erkens, 2006; Salomon \& Ben-Zvi, 2006; Stahl, 2006). Research indicates that hybrid learning has the tendency to involve learners in active and constructive learning. The scholars believe that constructive framework ignites promises of hybrid learning. The findings of the present study strongly coincide with the results of Edalati (2013), who believes that participants attached highest preference to the hybrid learning and expressed their satisfaction towards it. They acknowledged that hybrid learning enhanced their autonomy and knowledge of the vocabulary. The learners have attached maximum favouring responses, i.e., $83.33 \%$, which indicate that hybrid learning provided them effective learning experience. Likewise, the next least preferred item remains the one that elicits learners' perception related to the supposition, which mentions that hybrid learning open ways for them to easily cheat and plagiarize. The mean value of $($ mean $=3.36)$ by the female learners and (mean $=3.02)$ by their male counter-part suggests that participants do not agree with the assumption that hybrid learning furnishes opportunity for cheating and plagiarism. One of the survey questions in the study of Peytcheva-Forsyth, Aleksieva and Yovkova (2018) addresses to the learners about the issue of plagiarism and cheating in their university education. The responses were surprisingly different with variety of answers from number of students, such as; one student accepted that many times he did cheating/plagiarism, 20 students acknowledged that sometimes they committed it, $40 \%$ of the students mentioned of rare commission of the action and $50 \%$ of the students denied the action in question. In 
this context, Underwood (2006) expresses that he finds no evidence that internet has any impact on the increase of cheating as some other studies have made this claim. At the same time, he mentions that plagiarism does not have inherent connection with the internet; it does exist with or without it. He expresses that internet can be a tool for fast and easy cheating. The results of the study of Lee-Post and Hapke (2017) indicate that $45 \%$ of their learners found the cheating easy in online courses and 30\% learners affirm that they would not hesitate to cheat if they get an opportunity to do it. The participants of the study of Kocdar, Karadeniz, Peytcheva-Forsyth and Stoeva (2018), while responding to the open-ended questions have shown their sensitivity towards the subject of cheating and plagiarism and have clarified their position on the subject.

Table 5. EFL learners' satisfaction with the course content, and interactive and collaborative activities

\begin{tabular}{|c|c|c|c|c|c|c|c|}
\hline No & Statements & Group & $\mathrm{N}$ & $M$ &. $\mathrm{df}$ & P value & \\
\hline \multirow[t]{2}{*}{14.} & \multirow{2}{*}{$\begin{array}{l}\text { Hybrid learning ingrain insight of the "course content" more } \\
\text { widely and effectively. }\end{array}$} & $\mathrm{F}$ & 85 & 3.7412 & 165 & $\mathrm{p}>.357$ & No \\
\hline & & M & 82 & 3.5488 & 164.994 & .357 & \\
\hline \multirow[t]{2}{*}{15.} & \multirow{2}{*}{$\begin{array}{l}\text { Online and onsite channels of instruction provide opportunity for } \\
\text { frequent interaction with the course content and variety of } \\
\text { resources. }\end{array}$} & $\mathrm{F}$ & 82 & 3.4976 & 165 & $\mathrm{p}>.133$ & No \\
\hline & & M & 85 & 3.8073 & 164.875 & .132 & \\
\hline \multirow[t]{2}{*}{16.} & \multirow{2}{*}{$\begin{array}{l}\text { Face-to-face and virtual modes of instruction provide } \\
\text { opportunities for social gatherings, online interaction and better } \\
\text { learning experience. }\end{array}$} & $\mathrm{F}$ & 85 & 3.8000 & 165 & $\mathrm{p}>.880$ & No \\
\hline & & M & 82 & 3.7683 & 163.901 & .880 & \\
\hline \multirow[t]{2}{*}{17.} & \multirow{2}{*}{$\begin{array}{l}\text { Hybrid learning dispenses opportunities to learn through } \\
\text { discussions, collaboration and furnish variety of material and } \\
\text { resources for learning. }\end{array}$} & F & 85 & 3.8471 & 165 & $\mathrm{p}>.744$ & No \\
\hline & & M & 82 & 3.7805 & 164.628 & .744 & \\
\hline
\end{tabular}

Table 5 rakes descriptive statistics of the responses of male and female participants of the survey regarding their satisfaction towards the course content and their involvement in learner centered activities. This section contains 3 items in total and all have been assigned medium high mean value of more than 3 . In this category, item 17 states that, 'hybrid learning dispenses opportunities to learn through discussions, collaboration and furnish variety of material and resources for learning', has received maximum favoring responses from the participants in this cluster as indicated by the high mean value of $($ mean $=3.84)$ and $($ mean $=3.78)$, alternatively. The results of the present study coincide with the study of Fushino (2010), who reports that group work certainly reinforces oral communication, curiosity of the learners, social responsibility and learning outcomes. In the study of Abou Naaj et al. (2012), the item related to interaction among the learners has received highest mean value of 3.6 that is in-line with the present study.

The 2 nd highest preference was given to the item 16 with mean value of (mean $=3.80$ ) by the female and (mean $=3.76$ ) by the male participants. The item states that learners enjoy social gathering with their fellow peers in onsite classrooms and chat and discussions with their classmates in online sessions. The results of Buzzette-More's (2008) are in-line with the present study which reveals that $68.2 \%$ participants acknowledged that discussions enhance their learning experience of the course content, $69.3 \%$ concede that it regularly took place and $78.9 \%$ believe that it's an easy way of enhancing understanding of the subject through onsite and online channels of instructions. In the study of Bukhari and Basaffar (2019) majority of the learners believe that blended learning doesn't only provide effective peer-feedback and peer-interaction but also facilitate learner-teacher interaction and real-time teacher feedback. Similarly, the findings of the study of Caruso and Salaway (2007) are consistent with several studies undertaken in the same context indicating that majority of the students exhibited strong preferences for the hybrid learning model.

The participants have preferred item 15 with mean value of (mean $=3.80)$ by male learners and $($ mean $=3.49)$ by their female counterparts which mention that learners believe that online and onsite channels of instruction provide opportunity to the learners for frequent interaction with the course content and variety of resources. In the context of learners' interaction with the course content DeLacey and Leonard's (2002) study discovers students' interaction with the BL. They discuss that addition of online activities with the traditional courses not only heighten learners' insight of the course content but also improve their interaction and satisfaction. So and Brush (2008) support this view and state that convergence of traditional and virtual courses trigger learners interaction and satisfaction. Moreover, the results of the present study are in-line with the study of Caruso and Salaway (2007) and Wernet, Olliges and Delicath (2000) that blend of both the modes of instruction enhances learners' interaction with the several factors, including course content, instructor and other stake holders of the study. In this regard, Shantakumari and Sajith (2015) discuss learners' perceptions who believe that blended 
learning format of the course enhances their learning and also it was easy to follow. At the same time, learners acknowledge that online activities do not only focus on interaction but also their well-developed design enables them to meet the determined objectives.

The male and female participants of this survey have reacted with medium favoring responses to the item 14, which refers to the idea that, "Hybrid learning ingrain insight of "the course content" more widely and effectively". The item receives mean value of $($ mean $=3.74)$ from female participants and $(m e a n=3.54)$ from the male cohort, respectively. The results confirm the findings of Abbas (2018), who discusses that there are several factors which indicate that online and onsite modes of instruction enhance learners' interaction with the course content. The factors include flexibility of time (Atack \& Rankin, 2002), course design (Swan, 2001); and opportunities to participate in online discussion with their peers (Jiang \& Ting, 1999). The findings of the study of Buzzette-More (2008) are in-line with the present study, which mention that majority of the students have shown satisfaction with the course content available on the website. Overall results of the study of Buzzette-More (2008) reflect that hybrid learning in higher education enhances learners' satisfaction with the course content. The discussion reveals that $90 \%$ learners perceive that course websites are helpful resources and $85 \%$ believe that in future hybrid learning will have great impacts on higher education.

Table 6. EFL learners' satisfaction with interaction of instructor and their real-time feedback

\begin{tabular}{|c|c|c|c|c|c|c|c|}
\hline No & Statements & Group & $\mathrm{N}$ & $\mathrm{M}$ & .df & P value & \\
\hline \multirow[t]{2}{*}{18.} & Face-to-face instructions and Cambridge Learning & F & 85 & 3.6235 & 165 & $\mathrm{p}>.465$ & No \\
\hline & Management System (CLMS) supplement each other. & M & 82 & 3.5978 & 164.664 & .464 & \\
\hline \multirow[t]{2}{*}{19.} & Hybrid learning give(s) enormous opportunities for & $\mathrm{F}$ & 85 & 3.5176 & 165 & $\mathrm{p}>.340$ & No \\
\hline & $\begin{array}{l}\text { effective interaction between learner-learner and } \\
\text { teacher-learners in and beyond the classroom. }\end{array}$ & M & 82 & 3.5193 & 164.631 & .340 & \\
\hline \multirow[t]{2}{*}{20.} & I like real-time feedback of my teacher in face-to-face & $\mathrm{F}$ & 82 & 3.8824 & 165 & $\mathrm{p}>.198$ & No \\
\hline & and online modes of instructions. & M & 85 & 3.7920 & 164.988 & .198 & \\
\hline
\end{tabular}

Table 6 of the survey was meant to elicit Taif University's male and female EFL learners' satisfaction towards the instructor and their real-time feedback and interaction. This section includes results of three items related to the participants' responses collected through quantitative survey. A high mean value of (mean $=3.88$ ) was recorded by the female cohort to the item 20 which states that: 'I like real-time feedback of my instructor in face-to-face and online modes of instructions'. The male cohort has allocated (mean $=3.79)$ to this statement. Contrary to this are the findings of the study of Haytko (2001), who finds that hybrid course evaluations are seriously lower than the traditional course outcomes. Learners have reported dissatisfaction in the context of interaction with their instructor, however, the number of online interactions were notably higher than the on-site traditional course. Similar results have been traced back in the study of Marks, Sibley and Arbaugh (2005), who believe that interaction between instructor-student is the essence of online learning. Arbaugh and Benbunan-Fich (2007) report that learner-learner interaction is one of the strongest predictors of success in online instruction, whereas Hermans, Haytko and Mott-Stenerson (2009) declare that the lack of student-teacher interaction reduces learners' level of satisfaction with the course and the instructor.

The 2 nd highest importance was allocated to the item 18 , with mean value of (mean $=3.62)$ and $($ mean $=3.59)$ by the female and male cohort, which states that onsite and online channels of instructions complement each other. The results of the Buzzette-More (2008) research are similar to the findings of the present study which indicate that virtual and conventional modes of instructions supplement each other and combination of the both enhances students' learning experience (Allen \& Seaman, 2003; Buzzetto-More \& Sweat-Guy, 2006; Lorenzetti, 2005; Young, 2002). The findings of several other studies endorse learners' high-level satisfaction with the asynchronous instructions (Buzzetto-More \& Sweat-Guy, 2006; Sanders \& Morrison-Sheltar, 2002; Yip, 2004).

The average high mean value of (mean $=3.51)$ has been assigned unanimously to the assumption stated in item 19 that, 'hybrid learning give(s) enormous opportunities for effective interaction between learner-learner and teacher-learners in and beyond the classroom'. The study of Abbas (2018) explains that online course creates sense of community and social responsibility among the learners, where they freely communicate with each other. The frequent interaction among the learners evolves friendly online learning environment. His study receives $72 \%$ favouring responses to endorse the idea that onsite and online channels of instruction provide enormous opportunities for student-student interaction. Buzzette-More (2008) reports that $74.4 \%$ learners believe that it provides an opportunity to interact with their fellow peers and $71.6 \%$ assert that this approach facilitates 
asynchronous and real-time interaction with their teachers. Numerous scholars suggested that online mode of instruction enhances interaction between learner-learner and learner-instructor (Buzzetto-More \& Sweat-Guy, 2006; Carswell et al., 2000; Lesh et al., 2000). Similarly, the participants have endorsed that hybrid learning triggered their language learning process and made them independent learners beyond the limits of time and space. In addition to this, the results of the research of Abou Naaj et al. (2012) coincide with the findings of the present study, which reveal learners' highest satisfaction with the real-time feedback and interaction with the instructor. The participants allocated highest mean value of $($ mean $=3.8)$ to their satisfaction with the instructor. The results of the study of Abou Naaj et al. (2012) suggest that apart from the positive reaction towards the variables of satisfaction, dynamic performance, high grades of the learners both the genders prefer face-to-face classrooms over online learning environment. Majority of the participants of the present study have strongly validated instructor's real-time feedback and social interaction.

\section{Recommendations}

The analysis of data indicates learners' satisfaction towards the items of the survey designed and investigated in the present study. The research of Askar, Altun, and Ilgaz (2008) is in-line with the work in hand, who reports no significant differences in the satisfaction of male and female participants, however; they mention that score of female learners is slightly higher than their male counterparts for conventional face-to-face classrooms. For the present study following recommendations have been envisaged:

1) The instructor's attitude and expertise in developing learners' interest and motivation is significant for the successful implementation of hybrid learning environment. DeBourgh (2003) contends that learners' satisfaction and their subsequent enrollment in online courses greatly relies on the expertise of the instructor and the belief that how well the course was planned and taught by them. In the same manner, Ahmed (2010) too believes that instructor's control and mastery of the technology are the leading factors that motivate the learners for the acceptance of hybrid learning. In this context, researchers strongly recommend professional development of the teachers for the effective course delivery, dynamic interaction and rapport with the learners.

2) The "support system or help desk" is one of the significant components of e-learning approach. The support or help of the tutor and technical or IT staff is highlighted by many studies to improve the learning and successful delivery of the course (Bhalalusesa, 2001; Bollag et al., 2001; Simpson, 2004). In this backdrop, technical problems faced by the learners while using CLMS are vehemently highlighted by the male participants of the present study, whereas female participants have indicated their satisfaction towards this variable,

3) A general trend about technology-mediated instructions is that it is not as authentic and valid as conventional face-to-face instructions. In this context, Gammill et al. (2005) note that such stereotypical perceptions are promoted by the society at large, students and the teachers themselves, hence, would give serious challenges if not addressed properly (Rajesh, 2003; Usun, 2004). For this purpose, it is important to probe into the reason of such perceptions. At one end, though flexibility of time and place in e-learning is considered a safe haven as it reduces the participants' inconvenience but at another end, to some learners it provides an opportunity for escaping the lessons and class slots. Generally, for this reason people don't rely much on e-learning environment. At the same time, difficulty in perceived ease of use of technology and internet problem may also develop dissatisfaction towards e-learning. It is hereby strongly recommended that the incentive of marks should be kept for the attendance and class participation of the learners in different activities of e-learning environment and conventional classroom. It instills in learners' motivation and enthusiasm for ensuring their regular attendance and participation in the classroom.

4) By the same token, Anderson (2008) emphasizes that learners can get maximum benefits from technology-mediated instructions if course content is appropriately adapted and made consistent with the local culture, language and religious beliefs of that particular locality (Eastmond, 2000; Pagram et al., 2006; Usun, 2004). Learners' familiarity with their cultural norms and values heighten their understanding and insight of the course content and at the same time, they can relate subject matter of the activities with the real life like situations for their in-depth understanding.

5) Furthermore, the study recommends enhancing synchronous interaction between teacher to learners and learner to learner. Researchers greatly laid emphasis on the utilization of social interaction and collaboration in e-learning environment to trigger learners' satisfaction and insight about the subject matter. As for instance, American Psychological Association (1997) asserts that positive learning outcomes can be achieved by facilitating interactive activities among the learners (Bonk \& Cunningham, 1998; Gunawardena \& Zittle, 1998). This devise allows and encourages pair work, group work, discussions and role play in a virtual environment, henceforth, learners gain an in-depth insight and understanding of the course content. 
6) Last but not least, the proper check and balance of the organization is a strong indicator for the efficient delivery of hybrid instructions. Organizational support has wide-ranging impacts on the success of e-learning, such as; it does not only build learners' interest and inclination towards the acceptance of hybrid learning environment but also keeps the instructor motivated and well-prepared for the efficient delivery of the course content.

\section{Conclusion}

Measuring learners' satisfaction is significant to identify strengths and weaknesses of virtual and face-to-face learning environments. The inquiry was carried out to enable the administration to fix the issues and incorporate modifications for more effective, more robust and more efficient delivery of hybrid instructions. The statistical analysis of the data shows that EFL learners have indicated high satisfaction for hybrid learning environment and assigned maximum favoring responses to all the items of the survey. The findings of the study of Adas and Abu Shmais (2011) coincide with the present study, which reveal no significant differences in the satisfaction of male and female EFL cohort towards the effectiveness of hybrid learning. In the present study, three items of the survey indicate slight variation in male and female EFL learners' satisfaction towards hybrid learning. Male participants outnumbered female in attaching preference to the item 4 and 6 , mentioned in Tables 2 and 3 , respectively. With respect to these two items the findings of the study of Abou Naaj et al. (2012) coincide with the results of present study, who report that with blended learning male learners were more satisfied than female. The item 4 mentions that Cambridge Learning Management System (CLMS) allows learners to work in their own comfort zone, i.e., anytime and anyplace, which receives mean value of 4.89 and 3.42 from male and female EFL learners, alternatively. In this context, item 7 states that sometimes CLMS doesn't upgrade learners' progress and grades and report mean value of 4.83 and 3.86 for male and female EFL participants, respectively. In this regard, the significant variation between the mean values of both the participants clearly reveals low level satisfaction of the female participants towards the virtual platform.

However, female participants outscored male in assigning preference to the item 6, with mean value of 3.91 and 4.95 from male and female EFL learners alternatively, which refers that female participants feel more comfortable to complete online activities as compared to their male counterparts. The result of the research of Abou Naaj et al. (2012) is in-line with the present study, who express that blended learning has been perceived by most of the male and female learners less effective. They further note that, generally both the genders have preferred face-to-face learning environment even though they scored and performed well in blended learning course as well. Whereas comparison of the statistical data of both the genders indicate that male participants have shown more satisfaction towards blended environment than their female counterparts. Nevertheless, findings of the present study are partially in-line with Al-Fadhli's (2008) research, who reports significant differences in the satisfaction of male and their female class-mates towards their e-learning program. In his study, female learners surpassed male participants in all the items of the survey in evaluating their e-learning program. Contrary to this, Koohang (2004) contends that male participants have assigned high preference for the blended learning components than their female counter-parts. Similar to the research in hand, result of Ahmed's (2010) work reveals positive attitude of the learners towards hybrid learning and strongly recommends integration of e-learning tools with traditional learning environment. Hybrid learning model encompasses several constructs, as for instance; physical meetings in the classrooms, collaborative social interactions, synchronous and asynchronous online chats and discussions, dynamic rapport between teacher-learner and learner-learner in both the paradigms, real-time interaction and feedback of the instructor, perfect course design for both the channels of instructions, technology driven assessment and face-to-face exams, if all the components work smoothly spark learners' motivation and satisfaction.

\section{References}

Abbas, Z. I. (2018). Blended Learning and Student Satisfaction: An Investigation into an EAP Writing Course. Advances in Language and Literary Studies, 9(1), 102-105. https://doi.org/10.7575/aiac.alls.v.9n.1p.102

Abou Naaj, M., Nachouki, M., \& Ankit, A. (2012). Evaluating student satisfaction with blended learning in a gender-segregated environment. Journal of Information Technology Education: Research, 11(1), 185-200. https://doi.org/10.28945/1692

Adas, D., \& Abu Shmais, W. (2011). Students' perceptions towards blended learning Environment using the OCC. An-Najah University Journal for Research-Humanities, 25(6), 1681-1710. Retrieved from http://hdl.handle.net/20.500.11888/2719

Ageel, M. (2011, September). The ICT proficiencies of university teachers in Saudi Arabia: A case study to identify challenges and encouragements. Hummingbird, University of Southampton's Doctoral Research 
Journal, 2, 55-60. Retrieved from https://eric.ed.gov/?id=ED540250

Ahmad, Z., \& Ismail, I. Z. (2013). Utilization of hybrid learning in accomplishing learning satisfaction as perceived by university student. International Journal of E-Education, E-Business, E-Management and E-Learning, 3(2), 98. https://doi.org/10.7763/IJEEEE.2013.V3.200

Ahmed, H. M. S. (2010). Hybrid E - Learning acceptance model: Learner perceptions. Decision Sciences Journal of Innovative Education, 8(2), 313-346. https://doi.org/10.1111/j.1540-4609.2010.00259.x

AK-12 Leadership Series. (2009). Blended Learning: Where Online and Face-Face Instruction Intersect for 21 st century Teaching and Learning. Eduviews Tm. Retrieved from http://www.blackboard.com/.../k12

Akkoyunlu, B., \& Soylu, M. Y. (2006). A study on students' views on blended learning environment. Turkish Online Journal of Distance Education, 7(3), 43-56. https://eric.ed.gov/?id=ED494342.

Al Alhareth, Y. (2013). E-Learning Contribution to the Enhancement of Higher Education Opportunities for Women in Saudi Arabia (Pilot Study). US-China Education Review A, 3(9), 637-648. https://doi.org/10.12691/education-3-1-3

Al-Fadhli, S. (2008). Students' perceptions of e-learning in Arab society: Kuwait University as a case study. E-Learning and Digital Media, 5(4), 418-428. https://doi.org/10.2304/elea.2008.5.4.418

Alebaikan, R., \& Troudi, S. (2010). Blended learning in Saudi universities: challenges and perspectives. ALT-J, 18(1), 49-59. https://doi.org/10.1080/09687761003657614

Ali, A., \& Smith, D. (2015). Comparing social isolation effects on students attrition in online versus face-to-face courses in computer literacy. Issues in Informing Science and Information Technology, 12(1), 11-20. https://doi.org/10.28945/2258

Allen, I. E., \& Seaman, J. (2003). Sizing the Opportunity: The Quality and Extent of Online Education in the United States, 2002 and 2003. Sloan Consortium (NJ1). Retrieved from http://sloanconsortium.org.https://eric.ed.gov/?id=ED530060

Allen, I. E., \& Seaman, J. (2013). Changing course: Ten years of tracking online education in the United States. Sloan Consortium. PO Box 1238, Newburyport, MA 01950. Retrieved from http://sloanconsortium.org.https://files.eric.ed.gov/fulltext/ED541571.pdf

Alshwiah, A. A. (2010). Effects of a blended learning strategy in teaching vocabulary on Premedical students' achievement. International Journal of Instructional Technology and Distance Learning, 7(2), 37-52. Retrieved from https://www.itdl.org/Journal/Feb_10/article02.htm

Alzahrani, M. G. (2017). The Developments of ICT and the Need for Blended Learning in Saudi Arabia. Journal of Education and Practice, 8(9), 79-87. Retrieved from http://iiste.org/Journals/index.php/JEP

Anderson, A. (2008). Seven major challenges for e-learning in developing countries: Case study eBIT, Sri Lanka. International Journal of Education and Development Using ICT, 4(3), 45-62. Retrieved from https://www.learntechlib.org/p/42324/.

Arbaugh, J. B., \& Benbunan-Fich, R. (2007). The importance of participant interaction in online environments. Decision Support Systems, 43(3), 853-865. https://doi.org/10.1016/j.dss.2006.12.013

Askar, P., Altun, A., \& Ilgaz, H. (2008). Learner satisfaction on blended learning. E-leader conference, Krakow, Poland.

Atack, L., \& Rankin, J. (2002). A descriptive study of registered nurses' experiences with web - based learning. Journal of Advanced Nursing, 40(4), 457-465. https://doi.org/10.1046/j.1365-2648.2002.02394.x

Badawi, M. F. (2009). Using blended learning for enhancing EFL prospective teachers' pedagogical knowledge and performance. Paper presented at the Learning \& Language-The Spirit of the Age Conference, Cairo, Egypt. Retrieved from https://files.eric.ed.gov/fulltext/ED504993.pdf

Banditvilai, C. (2016). Enhancing Students' Language Skills through Blended Learning. Electronic Journal of E-Learning, 14(3), 223-229. Retrieved from https://eric.ed.gov/?id=EJ1107134

Bärenfänger, O. (2005). Learning management: A new approach to structuring hybrid learning arrangements. Electronic Journal of Foreign Language Teaching, 2(2), 14-35. Retrieved from https://e-flt.nus.edu.sg/v2n22005/baerenfaenger.pdf

Belanger, F., \& Jordan, D. H. (Eds.). (1999). Evaluation and Implementation of Distance Learning: Technologies, Tools and Techniques: Technologies, Tools and Techniques. IGI Global. 
https://doi.org/10.4018/978-1-878289-63-6

Bhalalusesa, E. (2001). Supporting women distance learners in Tanzania. Open Learning: The Journal of Open, Distance and E-Learning, 16(2), 155-168. https://doi.org/10.1080/02680510120050316

Bielaczyc, K., Collins, A., O’Donnell, A. M., Hmelo-Silver, C. E., \& Erkens, G. (2006). Fostering knowledge-creating communities. Collaborative Learning, Reasoning, and Technology, 37-60. Retrieved from https://books.google.com.sa/books?

Biner, P. M., Dean, R. S., \& Mellinger, A. E. (1994). Factors underlying distance learner satisfaction with televised college-level courses. The American Journal of Distance Education, 8(1), 60-71. https://doi.org/10.1080/08923649409526845

Bollag, B., \& Overland, M. A. (2001). Developing countries turn to distance education. Chronicle of Higher Education, 47(40), 29-31.

Bollinger, D., \& Martindale, T. (2001). Student Satisfaction in an Online Master's Degree Program in Instructional Technology. Retrieved from https://eric.ed.gov/?id=ED470070

Bollinger, D. U., \& Martindale, T. (2004). Key factors for determining student satisfaction in Online courses. International Journal on E-Learning, 3(1), 61-67. Retrieved from https://www.learntechlib.org/primary/p/2226/

Bonk, C. J., \& Cunningham, D. J. (1998). Searching for learner-centered, constructivist, and sociocultural components of collaborative educational learning tools. Electronic Collaborators: Learner-Centered Technologies for Literacy, Apprenticeship, and Discourse, 25, 25-50. Retrieved from https://scholar.google.com/scholar?hl=en\&as_sdt=0\%2C5\&q=Bonk\%2C+C.+J.\%2C+\%26+Cunningham

Bonk, C. J., \& Graham, C. R. (2012). The handbook of blended learning: Global perspectives, local designs. John Wiley \& Sons.

Bower, B. L., \& Kamata, A. (2000). Factors influencing student satisfaction with online courses. Academic Exchange Quarterly, 4(3), 52-56.

Bowyer, J., \& Chambers, L. (2017). Evaluating blended learning: Bringing the elements together (vol. 23, pp. 17-26). Research Matters: A Cambridge Assessment Publication. Retrieved from https://www.cambridgeassessment.org.uk/Images/375446

Brandon, D. P., \& Hollingshead, A. B. (1999). Collaborative learning and computer-supported groups. Communication Education, 48(2), 109-126. https://doi.org/10.1080/03634529909379159

Broadbent, B. (2000). Anyone, Anytime, Anywhere E-training has taken the health and safety world by storm. Occupational Health and Safety Canada, 16(8), 50-52.

Brophy, J. (2000). Teaching. Educational Practices Series-1. Retrieved from http://www.ibe.unesco.org.https://eric.ed.gov/?id=ED440066

Bruckman, A. (2002). The future of e-learning communities. Communications of the ACM, 45(4), 60-63. https://doi.org/10.1145/505248.505274

Bukhari, S. S. F., \& Basaffar, F. M. (2019). EFL Learners' Perception about Integrating Blended Learning in ELT. Arab World English Journal (Special Issue), 5, 190-205. https://doi.org/10.24093/awej/call5.14

Buzzetto-More, N. (2008). Student perceptions of various e-learning components. Interdisciplinary Journal of E-Learning and Learning Objects, 4(1), 113-135. https://doi.org/10.28945/370

Buzzetto-More, N. A., \& Guy, R. (2006). Incorporating the hybrid learning model into minority education at a historically black university. Journal of Information Technology Education: Research, 5(1), 153-164. https://doi.org/10.28945/240

Buzzetto-More, N., \& Sweat-Guy, R. (2007). The technology ownership and information acquisition habits of $\mathrm{HBCU}$ freshmen. Interdisciplinary Journal of Information, Knowledge, and Management, 2(1), 59-72. https://doi.org/10.28945/3113

Campos, M., \& Harasim, L. (1999). Virtual-U: Results and challenges of unique field trials. The Technology Source, 6. Retrieved from http://ts.mivu.org/default.asp?show=article\&id=1034

Carswell, L., Thomas, P., Petre, M., Price, B., \& Richards, M. (2000). Distance education via the internet: the student experience. British Journal of Educational Technology, 31(1), 29-46. https://doi.org/10.1111/1467-8535.00133 
Caruso, J. B., \& Salaway, G. (2007). The ECAR study of undergraduate students and information technology. Boulder, CO: EDUCASE Center for Applied Research. Retrieved from http://www.educause.edu/ECAR/ECARStudyofStudentsandInformat/158586

Casella, G., Costagliola, G., Ferrucci, F., Polese, G., \& Scanniello, G. (2007). A SCORM Thin Client Architecture for E-Learning Systems Based on Web Services. International Journal of Distance Education Technologies, 5(1), 19-28, 30-36. https://doi.org/10.4018/jdet.2007010103

Chang, S. C., \& Tung, F. C. (2008). An empirical investigation of students' behavioural intentions to use the online learning course websites. British Journal of Educational Technology, 39(1), 71-83. https://doi.org/10.1111/j.1467-8535.2007.00742.x

Chang, V., \& Fisher, D. (2003). The validation and application of a new learning environment instrument for online learning in higher education. In Technology-rich learning environments: A future perspective (pp. 1-20). https://doi.org/10.1142/9789812564412_0001

Chiu, C. M., Hsu, M. H., Sun, S. Y., Lin, T. C., \& Sun, P. C. (2005). Usability, quality, value and e-learning continuance decisions. Computers \& Education, 45(4), 399-416. https://doi.org/10.1016/j.compedu.2004.06.001

Collins Cobuild English Dictionary. (1999). London, UK: HarperCollins Publishers.

Davis, F. D. (1993). User acceptance of information technology: system characteristics, user perceptions and behavioral impacts. International Journal of Man-Machine Studies, 38(3), 475-487. https://doi.org/10.1006/imms.1993.1022

Debourgh, G. A. (1999). Technology is the tool, teaching is the task: Student satisfaction in distance learning. In Society for Information Technology \& Teacher Education International Conference (pp. 131-137). Association for the Advancement of Computing in Education (AACE). Retrieved June 28, 2020, from https://www.learntechlib.org/primary/p/7521/.

DeBourgh, G. A. (2003). Predictors of student satisfaction in distance-delivered graduate nursing courses: What matters most? Journal of Professional Nursing, 19(3), 149-163. https://doi.org/10.1016/S8755-7223(03)00072-3

DeLacey, B. J., \& Leonard, D. A. (2002). Case study on technology and distance in education at the Harvard Business School. Journal of Educational Technology \& Society, 5(2), 13-28. https://www.jstor.org/stable/jeductechsoci.5.2.13

Delone, W. H., \& Mclean, E. R. (2003). The Delone and Mclean model of information systems success: a ten-year update. Journal of Management Information Systems, 19(4), 9-30. https://doi.org/10.1080/07421222.2003.11045748

Doll, W. J., \& Torkzadeh, G. (1988). The measurement of end-user computing satisfaction. MIS Quarterly, 12(2), 259-274. https://doi.org/10.2307/248851

Dori, Y. J., \& Belcher, J. (2005). How does technology-enabled active learning affect undergraduate students' understanding of electromagnetism concepts? Journal of the Learning Sciences, 14(2), 243-279. https://doi.org/10.1207/s15327809jls1402_3

Dziuban, C., \& Moskal, P. (2001). Evaluating distributed learning at metropolitan universities. Educause Quarterly, 24(4), 60-61. Retrieved from https://journals.iupui.edu/index.php/muj/article/view/19881/19576

Dziuban, C. D., Moskal, P., \& Hartman, J. (2005). Higher education, blended learning, and the generations: Knowledge is power-No more (pp. 88-89). Elements of quality online education: Engaging communities. Needham, MA: Sloan Center for Online Education. Retrieved from https://desarrollodocente.uc.cl/wp-content/uploads/2020/03/Knowledge_is_power_no_more.pdf

Eastmond, D. (2000). Realizing the promise of distance education in low technology countries. Educational Technology Research and Development, 48(2), 100-111. https://doi.org/10.1007/BF02313405

Easton, S. S. (2003). Clarifying the instructor's role in online distance learning. Communication Education, 52(2), 87-105. https://doi.org/10.1080/03634520302470

Edalati, S. I. (2013). Hybrid learning and Iranian EFL learners' autonomy in vocabulary Learning. Social and Behavioral Sciences, 93, 1587-1592. https://doi.org/10.1016/j.sbspro.2013.10.086

Finaly-Neumann, E. (1994). Course work characteristics and students' satisfaction with instructions. Journal of 
Instructional Psychology, 21(1), 14-24. https://psycnet.apa.org/record/1994-39255-001

Frankola, K. (2001). Why online learners drop out. WORKFORCE-COSTA MESA, 80(10), 52-61. Retrieved from https://coursecontent.ntc.edu/synchronous/why-online-learners-drop-ou.pdf

Fushino, K. (2010). Causal relationships between communication confidence, beliefs about group work, and willingness to communicate in foreign language group work. TESOL Quarterly, 44(4), 700-724. https://doi.org/10.5054/tq.2010.235993

Gammill, T., \& Newman, M. (2005). Factors Associated with Faculty Use of Web-based Instruction in Higher Education. Journal of Agricultural Education, 46(4), 60-71. https://doi.org/10.5032/jae.2005.04060

Giannousi, M., Vernadakis, N., Derri, V., Michalopoulos, M., \& Kioumourtzoglou, E. (2009). Students' satisfaction from blended learning instruction (vol. 1, pp. 61-68). Proceedings of the TCC Worldwide Online Conference. Retrieved from https://www.learntechlib.org/p/43782/

Gómez, J., \& Igado, M. (2008). Blended learning: The key to success in a training company. International Journal of Instructional Technology and Distance Learning, 5(8), 33-42. Retrieved from https://d1wqtxts1xzle7.cloudfront.net/57893696/ITDL.pdf?

Gulnaz, F., Althomali, A. D. A., \& Alzeer, D. H. (2020). An Investigation of the Perceptions and Experiences of the EFL Teachers and Learners About the Effectiveness of Blended Learning at Taif University. International Journal of English Linguistics, 10(1), 329-344. https://doi.org/10.5539/ijel.v10n1p329

Gunawardena, C. N., \& Zittle, R. H. (1998). Faculty development programmes in distance education in American higher education. Staff Development in Open and Flexible Learning, 105-114.

Hara, N., \& Kling, R. (2001). Student distress in web-based distance education. Educause Quarterly, 24(3), $68-69$.

Hara, N., \& Kling, R. (2003). Students' distress with a Web-based distance education course: An ethno-graphic study of participants' experiences. Turkish Online Journal of Distance Education, 4(1), 1-30.

Harasim, L. (1990). On-line education: An environment for collaboration and intellectual implication. In L. Harasim (Ed.), On-line education: Perspectives on a new environment (pp. 133-169). New York: Praeger.

Hasan, A.-S. (2006). An Agent-based Architecture for Developing E-learning System. Information Technology Journal, 5(1), 121-127. https://doi.org/10.3923/itj.2006.121.127

Haytko, D. L. (2001). Traditional versus hybrid course delivery systems: A case study of undergraduate marketing planning courses. Marketing Education Review, 11(3), 27-39. https://doi.org/10.1080/10528008.2001.11488755.

Hermans, C. M., Haytko, D. L., \& Mott-Stenerson, B. (2009). Student satisfaction in Web Enhanced learning environments. Journal of Instructional Pedagogies, 1, 1-19. Retrieved from http://aabri.com/manuscripts/09147.pdf

Hiltz, S. R. (1993). Correlates of learning in a virtual classroom. International Journal of Man-Machine Studies, 39(1), 71-98. https://doi.org/10.1006/imms.1993.1054

Hiltz, S. R. (1994). The virtual classroom: Learning without limits via computer networks. Intellect Books. Retrieved from https://books.google.com.sa/books?

Hung, Y. H., Chang, R. I., \& Lin, C. F. (2016). Hybrid learning style identification and developing adaptive problem-solving learning activities. Computers in Human Behavior, 55, 552-561. https://doi.org/10.1016/j.chb.2015.07.004

Isaacs, E. A., Morris, T., Rodriguez, T. K., \& Tang, J. C. (1995). A comparison of face-to-face and distributed presentations. In R. R. Katz, R. Mack, L. Marks, M. B. Rosson \& J. Nelson (Eds.), Proceedings of the association for computing machinery (ACM) special interest group on computers and human interaction (CHI) 95 conference (pp. 354-361). New York: ACM Press. https://doi.org/10.1145/223904.223950

Jiang, M., \& Ting, E. (1999). A study of students' perceived learning in a web-based online environment. In WebNet World Conference on the WWW and Internet (pp. 575-580). Association for the Advancement of Computing in Education (AACE). Retrieved June 28, 2020 from https://www.learntechlib.org/primary/p/7481/

Jiang, M., \& Ting, E. (2000). A Study of Factors Influencing Students' Perceived Learning in a Web-Based Course Environment. International Journal of Educational Telecommunications, 6(4), 317-338. 
https://www.learntechlib.org/primary/p/8482/

Jones, P., Skinner, H., Wong, L., Tatnall, A., \& Burgess, S. (2014). A framework for investigating blended learning effectiveness. Education $+\quad$ Training. $\quad$ Retrieved from https://www.emerald.com/insight/content/doi/10.1108/ET-04-2013-0049/full/html

Kim, G. M., \& Ong, S. M. (2005). An exploratory study of factors influencing m-learning success. Journal of Computer Information Systems, 46(1), 92-97.

Kocdar, S., Karadeniz, A., Peytcheva-Forsyth, R., \& Stoeva, V. (2018). Cheating and plagiarism in e-assessment: students' perspectives. Open Praxis, 10(3), 221-235. https://doi.org/10.5944/openpraxis.10.3.873

Koohang, A. (2004). Students' perceptions toward the use of the digital library in weekly web-based distance learning assignments portion of a hybrid programme. British Journal of Educational Technology, 35, 617626. https://doi.org/10.1111/j.0007-1013.2004.00418.x

Kvavik, R. B., \& Caruso, J. B. (2009). Students and Information Technology, 2005: Convenience, connection, control, and learning. Educause Center for Applied Research. Retrieved from http://net.educause.edu/ir/library/pdf/ERS0506/ekf0506.Pdf.

Lalima, \& Dangwal, K. L. (2017). Blended Learning: An Innovative Approach. Universal Journal of Education Research, 5(1), 129-136. https://doi.org/10.13189/ujer.2017.050116

Launer, R. (2010). Five assumptions on blended learning: What is important to make blended learning a successful concept? Hybrid Learning Lecture Notes in Computer Science, 6248, 9-15. https://doi.org/10.1007/978-3-642-14657-2_2

Lee, B. C., Yoon, J. O., \& Lee, I. (2009). Learners' acceptance of e-learning in South Korea: Theories and results. Computers \& Education, 53(4), 1320-1329. https://doi.org/10.1016/j.compedu.2009.06.014

Lee-Post, A., \& Hapke, H. (2017). Online learning integrity approaches: Current practices and future solutions. Online Learning, 21(1), 135-145. https://doi.org/10.24059/olj.v21i1.843

Leidner, D. L., \& Jarvenpaa, S. L. (1995). The use of information technology to enhance management school education: A theoretical view. MIS Quarterly, 19(3), 265-291. https://doi.org/10.2307/249596

Lesh, S., Guffey, J., \& Rampp, L. (2000). Changes in student attitudes regarding a web-based health profession course (Reports - Research HE032863). U.S., Arkansas: Higher Education. Retrieved from https://eric.ed.gov/?id=ED441386

Levy, Y. (2007). Comparing dropouts and persistence in e-learning courses. Computers \& Education, 48(2), 185-204. https://doi.org/10.1016/j.compedu.2004.12.004

Lewis, C. (2002). Driving factors for e-learning: an organizational perspective. Perspectives, 6(2), 50-54. https://doi.org/10.1080/13603100120125979

Liaw, S. S., \& Huang, H. M. (2013). Perceived satisfaction, perceived usefulness and interactive learning environments as predictors to self-regulation in e-learning environments. Computers \& Education, 60(1), 14-24. https://doi.org/10.1016/j.compedu.2012.07.015

Lin, Q. (2008-2009). Student views of hybrid learning: A one-year exploratory study. Journal of Computing in Teacher Education, 25(2), 57-66. https://doi.org/10.1080/10402454.2008.10784610

Lindgaard, G., \& Dudek, C. (2003). What is this evasive beast we call user satisfaction? Interacting with Computers, 15(3), 429-452. https://doi.org/10.1016/S0953-5438(02)00063-2

Liu, S. H., Liao, H. L., \& Pratt, J. A. (2009). Impact of media richness and flow on e-learning technology acceptance. Computers \& Education, 52(3), 599-607. https://doi.org/10.1016/j.compedu.2008.11.002

Long, H. B (1985). Contradictory expectations: Achievement and satisfaction in adult learning. Journal of Continuing Higher Education, 33(3), 10-12. https://doi.org/10.1080/07377366.1985.10401035.

Lorenzetti, J. (2005). Lessons learned about student issues in online learning. Distance Education Report, 9(6), $1-4$.

Marks, R. B., Sibley, S. D., \& Arbaugh, J. B. (2005). A structural equation model of predictors for effective online learning. Journal of Management Education, 29(4), 531-563. https://doi.org/10.1177/1052562904271199

Martins, L. L., \& Kellermanns, F. W. (2004). A model of business school students' acceptance of a web-based 
course management system. Academy of Management Learning \& Education, 3(1), 7-26. https://doi.org/10.5465/amle.2004.12436815

Mason, R., \& Rennie, F. (2006). E-Learning: The Key Concepts. Routlege, Abingdon Great Britain. Retrieved from https://books.google.com.sa/books?

Mason, R., \& Weller, M. (2000). Factors affecting students' satisfaction on a web course. Australian Journal of Educational Technology, 16(2), 173-200. https://doi.org/10.14742/ajet.1830

Matheos, K., \& Curry, J. (2004). Online learning: Changes policies and practices. In Occasional Papers in High Education Number 12, Advances and Challenges in e-learning at Canadian Research Universities, Centre for Higher education Research and Development, University of Manitoba.

Mood, T. A. (1995). Distance education: An annotated bibliography. Libraries Unlimited, Inc., PO Box 6633, Englewood, CO 80155-6633. Retrieved from https://eric.ed.gov/?id=ED380113

Moore, M. G., \& Kearsley, G. G. (1996). Distance education: A system view. Wadsworth. Retrieved from https://agris.fao.org/agris-search/search.do?recordID=XL2012000215

Moore, M. G., \& Kearsley, G. (2011). Distance education: A systems view of online learning. Cengage Learning. Retrieved from https://books.google.com.sa/books?

Noytim, U. (2006). The impact of the internet on English language teaching: A case study at a Rajabhat University. Unpublished thesis, Faculty of Education, Sydney: University of Technology. Retrieved from http://hdl.handle.net/10453/20339

Oliver, M., \& Trigwell, K. (2005). Can 'blended learning' be redeemed? E-Learning, 2(1), $17-26$. https://doi.org/10.2304/elea.2005.2.1.17

Paechter, M. (2004). Hybrid learning leads to better achievement and higher satisfaction than pure e-learning. Is it that easy (vol. 2, pp. 584-591)? Proceedings of IKNOW '04, Graz, Austria, June 30-July. Retrieved from https://www.researchgate.net/profile/Manuela_Paechter/publication/268293713

Pagram, P., \& Pagram, J. (2006). Issues in E-Learning: A Thai Case Study. The Electronic Journal of Information Systems in Developing Countries, $26(1), \quad$ 1-8. https://doi.org/10.1002/j.1681-4835.2006.tb00175.x

Peytcheva-Forsyth, R., Aleksieva, L., \& Yovkova, B. (2018). The impact of technology on cheating and plagiarism in the assessment-The teachers' and students' perspectives. In AIP conference proceedings (Vol. 2048, No. 1, p. 020037). AIP Publishing LLC. https://doi.org/10.1063/1.5082055

Piccoli, G., Ahmad, R., \& Ives, B. (2001). Web-based virtual learning environments: a research framework and a preliminary assessment of effectiveness in basic IT skill training. MIS Quarterly, 25(4), 401-426. https://doi.org/10.2307/3250989

Pöysä, J., Lowyck, J., \& Häkkinen P. (2005). Learning together "there"-hybrid "place" as a conceptual vantage point for understanding virtual learning communities in higher education context. Psychology Journal, 3(2), 162-180. https://www.researchgate.net/profile/Joost_Lowyck/publication/220168822

Qindah, S. (2018). The effects of blended learning on EFL students' usage of grammar in context. The Eurasia Proceedings of Educational \& Social Sciences, 10, 11-22.

Rajesh, M. (2003). A Study of the problems associated with ICT adaptability in Developing Countries in the context of Distance Education. Turkish Online Journal of Distance Education, 4(2), 1-10. https://dergipark.org.tr/en/pub/tojde/issue/16936/176810

Rivera, J., McAlister, K., \& Rice, M. (2002). A comparison of student outcomes \& satisfaction between traditional \& web-based course offerings. Online Journal of Distance Learning Administration, 5(3), $151-179$.

Sagarra, N., \& Zapata, G. C. (2008). Blending classroom instruction with online homework: A study of student perceptions of computer-assisted L2 learning. ReCALL, 20(2), 208-224. https://doi.org/10.1017/S0958344008000621

Salomon, G., \& Ben-Zvi, D. (2006). The difficult marriage between education and technology: Is the marriage doomed (pp. 209-222). Instructional psychology: Past, present and future trends: Essays in honor of Erik De Corte.

Salmon, G. (2000). Computer mediated conferencing for management learning at the Open University. 
Management Learning, 31(4), 491-502. https://doi.org/10.1177/1350507600314005

Sanders, D., \& Morrison-Shetlar, A. (2002). Student attitudes toward web-enhanced instruction in an introductory biology course. Journal of Research on Computing in Education, 33(3), 251-262. https://doi.org/10.1080/08886504.2001.10782313

Schaeffer, C. E., \& Konetes, G. D. (2010). Impact of learner engagement on attrition rates and student success in online learning. International Journal of Instructional Technology \& Distance Learning, 7(5), 3-9. Retrieved from http://itdl.org/Journal/May_10/article01.htm

Shams, I. E. (2013). Hybrid learning and Iranian EFL learners' autonomy in vocabulary learning. Procedia-Social and Behavioral Sciences, 93, 1587-1592. https://doi.org/10.1016/j.sbspro.2013.10.086

Shantakumari, N., \& Sajith, P. (2015). Blended learning: The student viewpoint. Annals of Medical and Health Sciences Research, 5(5), 323-328. https://doi.org/10.4103/2141-9248.165248

Shee, D. Y., \& Wang, Y. S. (2008). Multi-criteria evaluation of the web-based e-learning system: A methodology based on learner satisfaction and its applications. Computers \& Education, 50(3), 894-905. https://doi.org/10.1016/j.compedu.2006.09.005

Simpson, O. (2004). The impact on retention of interventions to support distance learning students. Open Learning: The Journal of Open, Distance and E-Learning, 19(1), 79-95. https://doi.org/10.1080/0268051042000177863

Sitter, V., Carter, C. S., Mahan, R. P., Massello, C., \& Carter, T. J. (2009). Hybrid Course Design: Faculty and Student Perceptions (p. 40). Association of Small Computer Users in Education "Our Second Quarter Century of Resource Sharing". Retrieved from http://www.ascue.org

Skibba, K. A. (2006). A cross-case analysis of how faculty connect learning in a hybrid course (pp. 346-352). Proceedings of 47th Annual Adult Education Research Conference. Minneapolis, MN: University of Minnesota. Retrieved from https://d1wqtxts1 xzle7.cloudfront.net/32577954/Skibba.pdf?

Smith, P. L., \& Dillon, C. L. (1999). Comparing distance learning and classroom learning: Conceptual considerations. The American Journal of Distance Education, 13(2), 6-23. https://doi.org/10.1080/08923649909527020

So, H. J., \& Brush, T. A. (2008). Student perceptions of collaborative learning, social presence and satisfaction in a blended learning environment: Relationships and critical factors. Computers \& Education, 51(1), 318-336. https://doi.org/10.1016/j.compedu.2007.05.009

Stahl, G. (2006). Group cognition: Computer support for building collaborative knowledge. Cambridge, MA: MIT press. https://doi.org/10.7551/mitpress/3372.001.0001

Stodel, E. J., Thompson, T. L., \& MacDonald, C. J. (2006). Learners' perspectives on what is missing from online learning: Interpretations through the community of inquiry framework. The International Review of Research in Open and Distance Learning, 7(3). https://doi.org/10.19173/irrodl.v7i3.325

Summers, J., Waigandt, R., \& Whittaker, T. (2005). A comparison of student achievement and satisfaction in an online versus a traditional FTF statistics class. Innovative Higher Education, 29(3), 233-250. https://doi.org/10.1007/s10755-005-1938-x

Sun, P. C., Tsai, R. J., Finger, G., Chen, Y. Y., \& Yeh, D. (2008). What drives a successful e-Learning? An empirical investigation of the critical factors influencing learner satisfaction. Computers \& Education, 50(4), 1183-1202. https://doi.org/10.1016/j.compedu.2006.11.007

Swan, K. (2001). Virtual interaction: Design factors affecting student satisfaction and perceived learning in asynchronous online courses. Distance Education, 22(2), 306-331. https://doi.org/10.1080/0158791010220208

Tagoe, M. (2012). Students' perceptions on incorporating e-learning into teaching and learning at the University of Ghana. International Journal of Education and Development Using ICT, 8(1), 91-103. https://www.learntechlib.org/p/42295/.

Taylor, J. (1996). The continental classroom: Teaching labor studies on-line. Labor Studies Journal, 21, 19-38. Retrieved from https://heinonline.org/HOL/LandingPage?

Thompson, G. M. (2003). Bridging the gap: moving toward a blended learning environment (pp. 122-123). In Proceedings of the Marketing Management Association 8th Annual Educators' Conference. Retrieved from 
http://www.mmaglobal.org/publications/Proceedings/2003-MMA-Fall-Educators-

Underwood, J. D. (2006). Digital technologies and dishonesty in examinations and tests. Nottingham Trent University. Retrieved from https://core.ac.uk/download/pdf/4156559.pdf

Usun, S. (2004). Factors Affecting the Application of Information and Communication Technologies (ICT) in Distance Education. Turkish Online Journal of Distance Education, 5(1), 1-16. https://eric.ed.gov/?id=ED494441.

Viadero, D. (February 1999). Lighting the flame. Education Week, 18(22), 24-26. Retrieved from http://www.edweek.org/ew/articles/1999/02/10/22motiv.h18.html

Virvou, M., \& Katsionis, G. (2008). On the usability and likeability of virtual reality games for education: The case of VR-ENGAGE. Computers \& Education, 50(1), 154-178. https://doi.org/10.1016/j.compedu.2006.04.004

Waddoups, G. L., \& Howell, S. L. (2002). Bringing online learning to campus: The hybridization of teaching and learning at Brigham Young University. The International Review of Research in Open and Distributed Learning, 2(2). https://doi.org/10.19173/irrodl.v2i2.52

Wang, Y.-S. (2003). Assessment of learner satisfaction with asynchronous electronic learning systems. Information \& Management, 41(1), 75-86. https://doi.org/10.1016/S0378-7206(03)00028-4

Webster, J., \& Hackley, P. (1997). Teaching effectiveness in technology-mediated distance learning. Academy of Management Journal, 40(6), 1282-1309. https://doi.org/10.5465/257034

Wegerif, R. (1998). The social dimension of asynchronous learning networks. Journal of Asynchronous Learning Networks, 2(1), 34-49. $\quad$ Retrieved from https://www.researchgate.net/profile/Rupert_Wegerif/publication/228598781_The_Social_Dimension_of_A synchronous_Learning_Networks/links/09e-415124c0b8ebadf000000.pdf

Wernet, S., Olliges, R., \& Delicath, T. (2000). Post course evaluations of WebCT (Web Course Tools) classes by social work students. Research on Social Work Practice, 10(4), 487-504. https://doi.org/10.1177/104973150001000408

Williams, W. M., \& Ceci, S. J. (1997). "How am I doing?" Problems with student ratings of instructors and courses. Change: The Magazine of Higher Learning, 29(5), 12-23. https://doi.org/10.1080/00091389709602331

Wingo, N. P., Ivankova, N. V., \& Moss, J. A. (2017). Faculty perceptions about teaching online: exploring the literature using the technology acceptance model as an organizing framework. Online Learning, 21(1), 15-35. https://doi.org/10.24059/olj.v21i1.761

Wiriyachitra, A. (2002). English-language teaching and learning in Thailand in this decade. Thai Tesol Focus, 15(1), 4-9.

Woods, R., Baker, J., \& Hopper, D. (2004). Hybrid structures: Faculty use and perception of Web-based courseware as a supplement to FTF instruction. Internet \& Higher Education, 7(4), 281-297. https://doi.org/10.1016/j.iheduc.2004.09.002

Wu, D., \& Hiltz, R. (2004). Predicting learning from asynchronous online discussions. Journal of Asynchronous Learning Networks, 8(2), 139-152. https://d1wqtxts1xzle7.cloudfront.net/30276661/.

Wu, J. H., Tennyson, R. D., \& Hsia, T. L. (2010). A study of student satisfaction in a blended e-learning system environment. Computers \& Education, 55(1), 155-164. https://doi.org/10.1016/j.compedu.2009.12.012

Yip, M. C. W. (2004). Using WebCT to teach courses online. British Journal of Educational Technology, 35(4), 497-501. https://doi.org/10.1111/j.0007-1013.2004.00407.x

Young, J. (2002). Hybrid teaching seeks to end the divide between traditional and online instruction. Chronicle of Higher Education, 48(28), A33. Retrieved from https://ci.nii.ac.jp/naid/10012959701/

\section{Copyrights}

Copyright for this article is retained by the author, with first publication rights granted to the journal.

This is an open-access article distributed under the terms and conditions of the Creative Commons Attribution license (http://creativecommons.org/licenses/by/4.0/). 